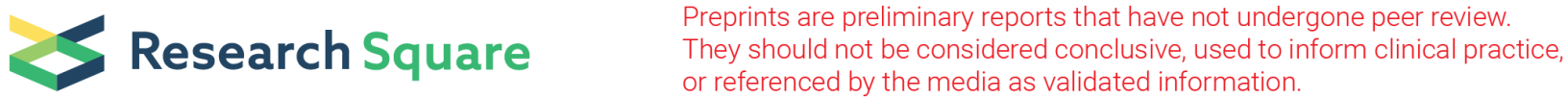 \\ Identification of a Promiscuous Conserved CTL Epitope Within the SARS-CoV-2 Spike Protein
}

\section{Sheng Jiang}

Key Laboratory of Medical Molecular Virology (MOE/NHC/CAMS), School of Basic Medical Sciences, Shanghai Medical College, Fudan University

Shuting Wu

Key Laboratory of Medical Molecular Virology (MOE/NHC/CAMS), School of Basic Medical Sciences, Shanghai Medical College, Fudan University

\section{Gan Zhao}

Advaccine Biopharmaceutics (Suzhou) Co. LTD

\section{Yue He}

Advaccine Biopharmaceutics (Suzhou) Co. LTD

\section{Xinrong Guo}

Colby College

\section{Zhiyu Zhang}

Advaccine Biopharmaceutics (Suzhou) Co. LTD

\section{Jiawang Hou}

Advaccine Biopharmaceutics (Suzhou) Co. LTD

\section{Yuan Ding}

Advaccine Biopharmaceutics (Suzhou) Co. LTD

\section{Alex Cheng}

Advaccine Biopharmaceutics (Suzhou) Co. LTD

Bin Wang ( $\sim$ bwang3@fudan.edu.cn )

Key Laboratory of Medical Molecular Virology (MOE/NHC/CAMS), School of Basic Medical Sciences, Shanghai Medical College, Fudan University

\section{Research Article}

Keywords: COVID-19 disease, CTL epitope, spike protein, Severe Acute Respiratory Syndrome Coronavirus 2 (SARS-CoV-2)

Posted Date: October 1st, 2021

DOI: https://doi.org/10.21203/rs.3.rs-936389/v1

License: (1) This work is licensed under a Creative Commons Attribution 4.0 International License. Read Full License 
Version of Record: A version of this preprint was published at Emerging Microbes \& Infections on February 16th, 2022. See the published version at https://doi.org/10.1080/22221751.2022.2043727. 


\section{Abstract}

The COVID-19 disease caused by infection with SARS-CoV-2 and its variants is devastating to the global public health and economy. To date, over a hundred COVID-19 vaccines are known to be under development and the few that have been approved to fight the disease are using the spike protein as the primary target antigen. Although virus neutralizing epitopes are mainly located within the RBD of the spike protein, the presence of T cell epitopes, particularly the CTL epitopes that are likely to be needed for killing infected cells, has received comparatively little attention. In this study, we predicted several potential T cell epitopes with web-based analytic tools, and narrowed them down from several potential MHC-I and MHC-II epitopes by ELIspot and cytolytic assays to a conserved MHC-I epitope. The epitope is highly conserved in current viral variants and compatible with presentation by most HLA alleles worldwide. In conclusion, we identified a CTL epitope suitable for evaluating the CD8+ T cell-mediated cellular response and potentially for addition into future COVID-19 vaccine candidates to maximize CTL responses against SARS-CoV-2.

\section{Introduction}

Severe Acute Respiratory Syndrome Coronavirus 2 (SARS-CoV-2) was first identified in Wuhan in early 2020, spread at unprecedented speed, and became a disaster to human beings worldwide ${ }^{1}$. Effective vaccines, antiviral drugs, and treatments have high priorities to defend against such challenges. SARS-CoV-2 has four main structural proteins: the envelope, membrane, nucleocapsid, and spike protein that can be considered for inclusion in vaccines. The spike protein has a receptor-binding domain (RBD) that specifically binds to human angiotensin-converting enzyme 2 (hACE2) as a receptor and mediates virus entry into the host cell ${ }^{2,3}$. Neutralizing antibodies recognizing the RBD can block the spike protein from binding to the hACE2 and inhibit virus entry ${ }^{4,5}$. Therefore, spike protein has been the primary choice as the immunogen in candidate vaccines.

Although protection against disease via vaccine-induced neutralizing antibodies has been demonstrated, the elimination of SARS-CoV-2 infection within the host is also essential. The numbers of mild and asymptomatic cases are rising dramatically in recent years and such cases remain infective, prolonging viral dissemination. To eliminate the viral infection, induction of a potent antigen-specific CD8+ T cell response by vaccination is probably critical. To activate a viral-specific $C D 8+T$ cell response, the vaccine must contain highly active major histocompatibility complex class I (MHC-I) epitopes that can be presented by MHC-I molecules to interact with $\mathrm{CD} 8+\mathrm{T}$ cell receptors (TCR). The potentiation of viral-specific CD8+ T cell responses is dependent upon the high affinity and avidity of MHC-I and TCR binding. There is a lack of information on the CD8+ T cellrecognized epitopes within the spike antigen; consequently, only overlapping peptide pools that covered the whole region of spike antigen have been used routinely to evaluate cell-mediated immunity (CMI) of a vaccine candidate $^{6,7,8}$. However, a few reports had suggested that CTL epitopes are present within the spike protein ${ }^{9}$, but no detailed mapping information had been reported or potential sequences discovered. The identification of those CD8+ T cell epitopes would provide an important tool to evaluate the $T$ cell immunity in vaccinated individuals or patients and was undertaken here.

This study utilized web-based tools to analyze the potentials for transportation associated with antigen processing (TAP) in the human MHC-I epitopes that were predicted by the Immune Epitope Database analysis (IEDB) resource ${ }^{10}$ to be present in peptide pools covering the $n$-terminal domain (NTD) and receptor-binding 
domain (RBD) of the spike protein. We demonstrated that peptide 2 (YYVGYLQPRTFLLKY), although it did not give the highest score in the web-based analysis of immunogenicity, was the best epitope for inducing a robust antigen-specific IFN-y producing CD8+ T response as defined by ELIspot assay. This epitope sequence is also highly conserved among currently discovered SARS-CoV-2 variants.

\section{Results}

Strong CD8+ CTL epitope activity is embedded in an overlapping peptide pool 1 that covers the NTD and RBD region of the spike protein

When Balb/c mice were immunized twice with the pGX9501 DNA vaccine expressing the spike protein of SARS-CoV-2, a higher level of IFN-y expression by splenocytes was often seen by the ELIspot assay when the cells were stimulated in vitro with spike peptide pool 1 (Table 1) compared with pool 2 (Figure 1A). In addition, when an in vivo CTL assay was done with identically immunized animals, the same peptide pool 1 gave a strong CTL response in vivo (Figure 1B), suggesting that MHC-I epitope(s) were present within pool 1. 
Table 1

Overlapping Peptide Pool 1.

\begin{tabular}{|c|c|c|c|c|}
\hline Peptide number & Sequence & Start & End & aa \\
\hline 1 & TAGAAAYYVGYLQPR & 258 & 272 & 15 \\
\hline 2 & YYVGYLQPRTFLLKY & 264 & 278 & 15 \\
\hline 3 & QPRTFLLKYNENGTI & 270 & 284 & 15 \\
\hline 4 & LKYNENGTITDAVDC & 276 & 290 & 15 \\
\hline 5 & GTITDAVDCALDPLS & 282 & 296 & 15 \\
\hline 6 & VDCALDPLSETKCTL & 288 & 302 & 15 \\
\hline 7 & PLSETKCTLKSFTVE & 294 & 308 & 15 \\
\hline 8 & CTLKSFTVEKGIYQT & 300 & 314 & 15 \\
\hline 9 & TVEKGIYQTSNFRVQ & 306 & 320 & 15 \\
\hline 10 & YQTSNFRVQPTESIV & 312 & 326 & 15 \\
\hline 11 & RVQPTESIVRFPNIT & 318 & 332 & 15 \\
\hline 12 & SIVRFPNITNLCPFG & 324 & 338 & 15 \\
\hline 13 & NITNLCPFGEVFNAT & 330 & 344 & 15 \\
\hline 14 & PFGEVFNATRFASVY & 336 & 350 & 15 \\
\hline 15 & NATRFASVYAWNRKR & 342 & 356 & 15 \\
\hline 16 & SVYAWNRKRISNCVA & 348 & 362 & 15 \\
\hline 17 & RKRISNCVADYSVLY & 354 & 368 & 15 \\
\hline 18 & CVADYSVLYNSASFS & 360 & 374 & 15 \\
\hline 19 & VLYNSASFSTFKCYG & 366 & 380 & 15 \\
\hline 20 & SFSTFKCYGVSPTKL & 372 & 386 & 15 \\
\hline 21 & CYGVSPTKLNDLCFT & 378 & 392 & 15 \\
\hline 22 & TKLNDLCFTNVYADS & 384 & 398 & 15 \\
\hline 23 & CFTNVYADSFVIRGD & 390 & 404 & 15 \\
\hline 24 & ADSFVIRGDEVRQIA & 396 & 410 & 15 \\
\hline 25 & RGDEVRQIAPGQTGK & 402 & 416 & 15 \\
\hline \multicolumn{5}{|l|}{ Notes: } \\
\hline \multicolumn{5}{|c|}{ 1. The peptides covered the entire sequence of $258-512$ amino acids in the spike protein; } \\
\hline $\begin{array}{l}\text { 2. The peptides } \\
\text { overlapping each }\end{array}$ & d with an average 15 & d with & $\operatorname{mino}$ & \\
\hline
\end{tabular}




\begin{tabular}{|lllll|}
\hline Peptide number & Sequence & Start & End & aa \\
\hline 26 & QIAPGQTGKIADYNY & 408 & 422 & 15 \\
\hline 27 & TGKIADYNYKLPDDF & 414 & 428 & 15 \\
\hline 28 & YNYKLPDDFTGCVIA & 420 & 434 & 15 \\
\hline 29 & DDFTGCVIAWNSNNL & 426 & 440 & 15 \\
\hline 30 & VIAWNSNNLDSKVGG & 432 & 446 & 15 \\
\hline 31 & NNLDSKVGGNYNYLY & 438 & 452 & 15 \\
\hline 32 & VGGNYNYLYRLFRKS & 444 & 458 & 15 \\
\hline 33 & YLYRLFRKSNLKPFE & 450 & 464 & 15 \\
\hline 34 & RKSNLKPFERDISTE & 456 & 470 & 15 \\
\hline 35 & PFERDISTEIYQAGS & 462 & 476 & 15 \\
\hline 36 & STEIYQAGSTPCNGV & 468 & 482 & 15 \\
\hline 37 & AGSTPCNGVEGFNCY & 474 & 488 & 15 \\
\hline 38 & NGVEGFNCYFPLQSY & 480 & 494 & 15 \\
\hline 39 & NCYFPLQSYGFQPTN & 486 & 500 & 15 \\
\hline 40 & QSYGFQPTNGVGYQP & 492 & 506 & 15 \\
\hline 41 & PTNGVGYQPYRVVVL & 498 & 512 & 15 \\
\hline Notes: & & & \\
\hline 1. The peptides covered the entire sequence of 258-512 amino acids in the spike protein; & \\
\hline 2. The peptides were synthesized with an average 15 amino acid length and with nine amino acids \\
\hline vverlapping each other. & & & \\
\hline
\end{tabular}

\section{Screening and identification of an MHC-I epitope in peptide pool 1.}

We placed the entire 41 peptide sequences from peptide pool 1 into the Immune Epitope Database analysis (IEDB) (http://www.iedb.org/) to seek critical epitopes. An evaluation method was established by integrating $\mathrm{MHC}-\mathrm{I}$ binding prediction, $\mathrm{MHC}-\mathrm{I}$ immunogenicity, and $\mathrm{MHC}$ natural processing (MHC-NP) prediction from three $\mathrm{H}-2 \mathrm{~d}$ MHC-I alleles to improve the accuracy of prediction results (Table 2). In the $\mathrm{H}-2 \mathrm{D}^{\mathrm{d}}$ allele, peptide 2 showed good MHC-I binding ability, immunogenicity, and TAP ability. In the $\mathrm{H}-2 \mathrm{~K}^{\mathrm{d}}$ allele, peptide 12 showed the strongest immunogenicity, and peptide 2 presented the most potent MHC-I binding ability and TAP ability among all peptides. In the $\mathrm{H}-2 \mathrm{~L}^{\mathrm{d}}$ allele, both peptide 2 and peptide 11 showed the strongest immunogenicity, while peptide 12 emerged as having the most potent TAP ability (Figure 2A\&2B). Consequently, we used peptide 2, peptide 11, and peptide 12 to conduct an ELIspot assay of T cell IFN-y response. 
Table 2

MHC-I epitope analysis for Overlapping Peptide Pool 1.

\begin{tabular}{|c|c|c|c|c|c|c|c|c|}
\hline allele & $\begin{array}{l}\text { peptide } \\
\text { number }\end{array}$ & $\begin{array}{l}\text { MHC-I } \\
\text { binding }\end{array}$ & immunogenicity & $\begin{array}{l}\text { Proteasome } \\
\text { Score }\end{array}$ & $\begin{array}{l}\text { TAP } \\
\text { Score }\end{array}$ & $\begin{array}{l}\text { MHC } \\
\text { Score }\end{array}$ & $\begin{array}{l}\text { Processing } \\
\text { Score }\end{array}$ & $\begin{array}{l}\text { TAP } \\
\text { Total } \\
\text { Score }\end{array}$ \\
\hline $\begin{array}{l}\mathrm{H}-2- \\
\mathrm{Dd}\end{array}$ & 21 & 0.01 & 0.03612 & 1.44 & 1.12 & -3.49 & 2.57 & -0.92 \\
\hline $\begin{array}{l}\mathrm{H}-2- \\
\mathrm{Dd}\end{array}$ & 41 & 0.04 & 0.13706 & 1.74 & 0.4 & -2.56 & 2.14 & -0.42 \\
\hline $\begin{array}{l}\mathrm{H}-2- \\
\mathrm{Dd}\end{array}$ & 2 & 0.05 & 0.1573 & 1.36 & 1.07 & -3.26 & 2.43 & -0.83 \\
\hline $\begin{array}{l}\mathrm{H}-2- \\
\mathrm{Dd}\end{array}$ & 26 & 0.13 & -0.02676 & 1.38 & 1.27 & -4.51 & 2.65 & -1.86 \\
\hline $\begin{array}{l}\mathrm{H}-2- \\
\mathrm{Dd}\end{array}$ & 9 & 0.19 & -0.11058 & 1.27 & 0.99 & -3.48 & 2.26 & -1.22 \\
\hline $\begin{array}{l}\mathrm{H}-2- \\
\mathrm{Dd}\end{array}$ & 19 & 0.25 & 0.03263 & 1.33 & 1.04 & -3.45 & 2.37 & -1.08 \\
\hline $\begin{array}{l}\mathrm{H}-2- \\
\text { Dd }\end{array}$ & 12 & 0.29 & 0.1431 & 1.05 & 1.29 & -3.9 & 2.35 & -1.55 \\
\hline $\begin{array}{l}\mathrm{H}-2- \\
\mathrm{Dd}\end{array}$ & 11 & 0.49 & 0.1386 & 1.36 & 1.21 & -4.02 & 2.57 & -1.45 \\
\hline $\begin{array}{l}\mathrm{H}-2- \\
\mathrm{Dd}\end{array}$ & 32 & 0.62 & 0.0966 & 1.19 & 1.17 & -3.83 & 2.36 & -1.46 \\
\hline $\begin{array}{l}\mathrm{H}-2- \\
\mathrm{Dd}\end{array}$ & 37 & 0.65 & 0.12191 & 1.38 & 1.09 & -3.76 & 2.47 & -1.29 \\
\hline $\begin{array}{l}\mathrm{H}-2- \\
\mathrm{Dd}\end{array}$ & 14 & 0.67 & 0.08562 & 1.39 & 0.82 & -3.76 & 2.21 & -1.55 \\
\hline $\begin{array}{l}\mathrm{H}-2- \\
\mathrm{Dd}\end{array}$ & 31 & 0.7 & 0.023 & 1.31 & 1.15 & -4.17 & 2.46 & -1.71 \\
\hline $\begin{array}{l}\mathrm{H}-2- \\
\mathrm{Dd}\end{array}$ & 20 & 0.7 & -0.31841 & 1.47 & 1.3 & -4.6 & 2.77 & -1.83 \\
\hline $\begin{array}{l}\mathrm{H}-2- \\
\mathrm{Dd}\end{array}$ & 27 & 0.89 & -0.11289 & 1.4 & 1.21 & -4.54 & 2.61 & -1.92 \\
\hline $\begin{array}{l}\mathrm{H}-2- \\
\mathrm{Dd}\end{array}$ & 28 & 1.1 & -0.19576 & 0.98 & 1.12 & -4.22 & 2.1 & -2.12 \\
\hline
\end{tabular}

Notes:

1. MHC-I binding score was between 0 and 2. $<0.5$ strong binder, $0.5-2$ weak binder, $>2$ non-binder.

2. A high Immunogenicity score indicates that the degree of the peptide conformity to sequence preference was good.

3. The higher the TAP total score, the higher the likelihood that the peptide will be presented after being swallowed by DCs. 


\begin{tabular}{|c|c|c|c|c|c|c|c|c|}
\hline allele & $\begin{array}{l}\text { peptide } \\
\text { number }\end{array}$ & $\begin{array}{l}\text { MHC-I } \\
\text { binding }\end{array}$ & immunogenicity & $\begin{array}{l}\text { Proteasome } \\
\text { Score }\end{array}$ & $\begin{array}{l}\text { TAP } \\
\text { Score }\end{array}$ & $\begin{array}{l}\text { MHC } \\
\text { Score }\end{array}$ & $\begin{array}{l}\text { Processing } \\
\text { Score }\end{array}$ & $\begin{array}{l}\text { TAP } \\
\text { Total } \\
\text { Score }\end{array}$ \\
\hline $\begin{array}{l}\mathrm{H}-2- \\
\text { Dd }\end{array}$ & 24 & 1.2 & 0.12947 & 1.27 & 0.71 & -4.63 & 1.98 & -2.64 \\
\hline $\begin{array}{l}\mathrm{H}-2- \\
\text { Dd }\end{array}$ & 25 & 1.2 & -0.11559 & 1.43 & 0.15 & -4.39 & 1.58 & -2.81 \\
\hline $\begin{array}{l}\mathrm{H}-2- \\
\text { Dd }\end{array}$ & 18 & 1.2 & -0.22309 & 1.33 & 1.17 & -4.05 & 2.5 & -1.55 \\
\hline $\begin{array}{l}\mathrm{H}-2- \\
\text { Dd }\end{array}$ & 40 & 1.3 & 0.1256 & 1.38 & 1.34 & -4.5 & 2.71 & -1.79 \\
\hline $\begin{array}{l}\mathrm{H}-2- \\
\text { Dd }\end{array}$ & 1 & 1.3 & 0.06158 & 1.24 & 1.23 & -4.32 & 2.47 & -1.85 \\
\hline $\begin{array}{l}\mathrm{H}-2- \\
\text { Dd }\end{array}$ & 33 & 1.5 & -0.21085 & 1.03 & 1.24 & -4.23 & 2.27 & -1.96 \\
\hline $\begin{array}{l}\mathrm{H}-2- \\
\text { Dd }\end{array}$ & 29 & 1.6 & 0.05792 & 1.52 & 0.5 & -4.17 & 2.02 & -2.15 \\
\hline $\begin{array}{l}\mathrm{H}-2- \\
\text { Dd }\end{array}$ & 30 & 1.6 & 0.05792 & 1.35 & 0.46 & -4.17 & 1.8 & -2.36 \\
\hline $\begin{array}{l}\mathrm{H}-2- \\
\text { Dd }\end{array}$ & 39 & 1.6 & -0.15021 & 1.25 & 1.15 & -3.84 & 2.41 & -1.44 \\
\hline $\begin{array}{l}\mathrm{H}-2- \\
\text { Dd }\end{array}$ & 10 & 2 & 0.01977 & 1.1 & 0.24 & -4.23 & 1.34 & -2.89 \\
\hline $\begin{array}{l}\mathrm{H}-2- \\
\mathrm{Kd}\end{array}$ & 2 & 0.01 & 0.06572 & 1.24 & 0.48 & -1.78 & 1.72 & -0.06 \\
\hline $\begin{array}{l}\mathrm{H}-2- \\
\mathrm{Kd}\end{array}$ & 41 & 0.05 & 0.04196 & 1.74 & 0.46 & -3.43 & 2.2 & -1.22 \\
\hline $\begin{array}{l}\mathrm{H}-2- \\
\mathrm{Kd}\end{array}$ & 9 & 0.06 & 0.12441 & 1 & 0.23 & -2.55 & 1.23 & -1.32 \\
\hline $\begin{array}{l}\mathrm{H}-2- \\
\mathrm{Kd}\end{array}$ & 4 & 0.07 & 0.28634 & 1.34 & 0.37 & -2.34 & 1.71 & -0.63 \\
\hline $\begin{array}{l}\mathrm{H}-2- \\
\mathrm{Kd}\end{array}$ & 3 & 0.07 & 0.05892 & 1.16 & 0.37 & -2.34 & 1.54 & -0.8 \\
\hline $\begin{array}{l}\mathrm{H}-2- \\
\mathrm{Kd}\end{array}$ & 20 & 0.08 & 0.25644 & 1.45 & 0.49 & -2.65 & 1.93 & -0.71 \\
\hline \multicolumn{9}{|c|}{ Notes: } \\
\hline \multicolumn{9}{|c|}{ 1. MHC-I binding score was between 0 and 2. $<0.5$ strong binder, $0.5-2$ weak binder, $>2$ non-binder. } \\
\hline \multicolumn{9}{|c|}{$\begin{array}{l}\text { 2. A high Immunogenicity score indicates that the degree of the peptide conformity to sequence preference } \\
\text { was good. }\end{array}$} \\
\hline
\end{tabular}




\begin{tabular}{|c|c|c|c|c|c|c|c|c|}
\hline allele & $\begin{array}{l}\text { peptide } \\
\text { number }\end{array}$ & $\begin{array}{l}\text { MHC-I } \\
\text { binding }\end{array}$ & immunogenicity & $\begin{array}{l}\text { Proteasome } \\
\text { Score }\end{array}$ & $\begin{array}{l}\text { TAP } \\
\text { Score }\end{array}$ & $\begin{array}{l}\text { MHC } \\
\text { Score }\end{array}$ & $\begin{array}{l}\text { Processing } \\
\text { Score }\end{array}$ & $\begin{array}{l}\text { TAP } \\
\text { Total } \\
\text { Score }\end{array}$ \\
\hline $\begin{array}{l}\mathrm{H}-2- \\
\mathrm{Kd}\end{array}$ & 21 & 0.08 & 0.05832 & 1.75 & 0.36 & -2.65 & 2.12 & -0.53 \\
\hline $\begin{array}{l}\mathrm{H}-2- \\
\mathrm{Kd}\end{array}$ & 16 & 0.11 & 0.16858 & 1.36 & 0.4 & -2.32 & 1.77 & -0.55 \\
\hline $\begin{array}{l}\mathrm{H}-2- \\
\mathrm{Kd}\end{array}$ & 40 & 0.19 & 0.0905 & 1.38 & 1.32 & -3.9 & 2.69 & -1.21 \\
\hline $\begin{array}{l}\mathrm{H}-2- \\
\mathrm{Kd}\end{array}$ & 23 & 0.26 & 0.0573 & 1.31 & 0.44 & -3.18 & 1.75 & -1.43 \\
\hline $\begin{array}{l}\mathrm{H}-2- \\
\text { Kd }\end{array}$ & 24 & 0.61 & -0.0378 & 1.07 & 0.2 & -3.02 & 1.27 & -1.75 \\
\hline $\begin{array}{l}\mathrm{H}-2- \\
\text { Kd }\end{array}$ & 19 & 0.68 & 0.0279 & 1.33 & 1.2 & -3.27 & 2.52 & -0.75 \\
\hline $\begin{array}{l}\mathrm{H}-2- \\
\mathrm{Kd}\end{array}$ & 10 & 0.79 & 0.034 & 1.1 & 0.23 & -3.35 & 1.33 & -2.02 \\
\hline $\begin{array}{l}\mathrm{H}-2- \\
\mathrm{Kd}\end{array}$ & 12 & 0.92 & 0.34063 & 1.45 & 0.59 & -3.13 & 2.03 & -1.1 \\
\hline $\begin{array}{l}\mathrm{H}-2- \\
\mathrm{Kd}\end{array}$ & 1 & 0.96 & -0.04018 & 1.24 & 1.29 & -4.51 & 2.53 & -1.98 \\
\hline $\begin{array}{l}\mathrm{H}-2- \\
\mathrm{Kd}\end{array}$ & 32 & 0.99 & 0.13255 & 1.19 & 1.18 & -3.56 & 2.37 & -1.19 \\
\hline $\begin{array}{l}\mathrm{H}-2- \\
\mathrm{Kd}\end{array}$ & 39 & 1.1 & 0.0801 & 1.25 & 1.31 & -3.16 & 2.56 & -0.6 \\
\hline $\begin{array}{l}\mathrm{H}-2- \\
\mathrm{Kd}\end{array}$ & 31 & 1.2 & 0.1811 & 1.48 & 0.48 & -3.32 & 1.96 & -1.36 \\
\hline $\begin{array}{l}\mathrm{H}-2- \\
\mathrm{Kd}\end{array}$ & 29 & 2 & 0.07062 & 1.52 & 0.5 & -3.5 & 2.02 & -1.48 \\
\hline $\begin{array}{l}\mathrm{H}-2- \\
\mathrm{Kd}\end{array}$ & 30 & 2 & 0.07062 & 1.35 & 0.46 & -3.5 & 1.8 & -1.7 \\
\hline $\begin{array}{l}\mathrm{H}-2- \\
\mathrm{Kd}\end{array}$ & 35 & 2 & -0.15381 & 1.42 & 1.16 & -4.52 & 2.57 & -1.95 \\
\hline $\begin{array}{l}\mathrm{H}-2- \\
\text { Ld }\end{array}$ & 11 & 0.06 & 0.30371 & 1.36 & 0.98 & -3.5 & 2.34 & -1.16 \\
\hline \multicolumn{9}{|c|}{ Notes: } \\
\hline \multicolumn{9}{|c|}{ 1. MHC-I binding score was between 0 and 2. $<0.5$ strong binder, $0.5-2$ weak binder, $>2$ non-binder. } \\
\hline \multicolumn{9}{|c|}{$\begin{array}{l}\text { 2. A high Immunogenicity score indicates that the degree of the peptide conformity to sequence preference } \\
\text { was good. }\end{array}$} \\
\hline
\end{tabular}




\begin{tabular}{|c|c|c|c|c|c|c|c|c|}
\hline allele & $\begin{array}{l}\text { peptide } \\
\text { number }\end{array}$ & $\begin{array}{l}\text { MHC-I } \\
\text { binding }\end{array}$ & immunogenicity & $\begin{array}{l}\text { Proteasome } \\
\text { Score }\end{array}$ & $\begin{array}{l}\text { TAP } \\
\text { Score }\end{array}$ & $\begin{array}{l}\text { MHC } \\
\text { Score }\end{array}$ & $\begin{array}{l}\text { Processing } \\
\text { Score }\end{array}$ & $\begin{array}{l}\text { TAP } \\
\text { Total } \\
\text { Score }\end{array}$ \\
\hline $\begin{array}{l}\mathrm{H}-2- \\
\text { Ld }\end{array}$ & 41 & 0.12 & -0.07228 & 1.74 & 0.35 & -3.54 & 2.09 & -1.45 \\
\hline $\begin{array}{l}\text { H-2- } \\
\text { Ld }\end{array}$ & 21 & 0.2 & 0.05832 & 1.44 & 0.99 & -3.65 & 2.44 & -1.21 \\
\hline $\begin{array}{l}\mathrm{H}-2- \\
\text { Ld }\end{array}$ & 39 & 0.27 & -0.19696 & 1.25 & 0.91 & -3 & 2.16 & -0.84 \\
\hline $\begin{array}{l}\text { H-2- } \\
\text { Ld }\end{array}$ & 12 & 0.28 & 0.09851 & 1.05 & 0.94 & -2.75 & 2 & -0.75 \\
\hline $\begin{array}{l}\mathrm{H}-2- \\
\text { Ld }\end{array}$ & 37 & 0.44 & 0.0801 & 1.38 & 0.99 & -4.01 & 2.37 & -1.65 \\
\hline $\begin{array}{l}\mathrm{H}-2- \\
\mathrm{Ld}\end{array}$ & 2 & 0.54 & 0.28634 & 1.41 & 1.19 & -3.97 & 2.6 & -1.38 \\
\hline $\begin{array}{l}\text { H-2- } \\
\text { Ld }\end{array}$ & 3 & 0.57 & -0.08994 & 1.52 & 1.13 & -3.97 & 2.65 & -1.32 \\
\hline $\begin{array}{l}\mathrm{H}-2- \\
\mathrm{Ld}\end{array}$ & 27 & 0.77 & 0.0573 & 1.4 & 1.21 & -4.39 & 2.61 & -1.78 \\
\hline $\begin{array}{l}\text { H-2- } \\
\text { Ld }\end{array}$ & 28 & 0.77 & 0.03448 & 0.98 & 1.12 & -4.18 & 2.1 & -2.07 \\
\hline $\begin{array}{l}\text { H-2- } \\
\text { Ld }\end{array}$ & 19 & 0.95 & 0.11915 & 1.53 & 1.42 & -4.32 & 2.95 & -1.37 \\
\hline $\begin{array}{l}\text { H-2- } \\
\text { Ld }\end{array}$ & 18 & 1.1 & -0.22669 & 1.33 & 1.17 & -3.82 & 2.5 & -1.32 \\
\hline $\begin{array}{l}\text { H-2- } \\
\text { Ld }\end{array}$ & 34 & 1.9 & 0.1811 & 0.91 & 1.16 & -4.58 & 2.07 & -2.5 \\
\hline $\begin{array}{l}\mathrm{H}-2- \\
\mathrm{Ld}\end{array}$ & 9 & 1.9 & -0.08994 & 1.27 & 0.99 & -4.13 & 2.26 & -1.87 \\
\hline $\begin{array}{l}\mathrm{H}-2- \\
\mathrm{Ld}\end{array}$ & 38 & 2 & -0.19696 & 0.99 & 0.28 & -2.8 & 1.27 & -1.53 \\
\hline \multicolumn{9}{|c|}{ Notes: } \\
\hline \multicolumn{9}{|c|}{ 1. MHC-I binding score was between 0 and 2. $<0.5$ strong binder, $0.5-2$ weak binder, $>2$ non-binder. } \\
\hline \multicolumn{9}{|c|}{$\begin{array}{l}\text { 2. A high Immunogenicity score indicates that the degree of the peptide conformity to sequence preference } \\
\text { was good. }\end{array}$} \\
\hline \multicolumn{9}{|c|}{$\begin{array}{l}\text { 3. The higher the TAP total score, the higher the likelihood that the peptide will be presented after being } \\
\text { swallowed by DCs. }\end{array}$} \\
\hline
\end{tabular}

As shown in Figure 3A, peptide 2 from pool 1 presented the best stimulation to induce the IFN- $\gamma$ secretion compared to the other two selected peptides. Thus, peptide 2, consisting of 15 amino acids, stimulated CD8+ T 
cells via MHC-I or/and CD4+ T cells via MHC-II. To identify which T cell type was stimulated by peptide 2 , purified CD4+ T cells or CD8+ T cells were used (sFigure 1). Peptide 2 stimulated CD8+ T cells but not CD4+ cells, indicating that it can only be presented by MHC-I (Figure 3B). To further investigate its sequence specificity, we mutated several predicted anchor amino acids of peptide 2 according to the preferences of the $\mathrm{H}-2 \mathrm{~d}$ MHC-I allele ${ }^{11-14}$. The mutated peptide 2 had a low MHC-I binding score in the IEDB prediction (Table 3) and showed a significantly reduced ability to stimulate IFN-y secretion by CD8+ T cells (Figure 3C).

Table 3

Prediction scores of peptide 2 and mutated peptide 2

\begin{tabular}{|llll|}
\hline & \multicolumn{1}{|c|}{ Sequence } & Score & MHC-I binding \\
\hline Peptide 2 & YYVGYLQPRTFLLKY & 0.91863 & 0.01 \\
\hline Peptide 2 mut & YEVGELQDRTFELKY & 0.025669 & $>2$ \\
\hline Notes: & & \\
\hline $\begin{array}{l}\text { 1. } \text { MHC-l binding score was between 0 and 2, where, the <0.5 represents a strong binder, 0.5-2 weak binder, } \\
>2 \text { non-binder. }\end{array}$ & \\
\hline 2. Underlined amino acids were the mutated residues in the Peptide 2 mut. & \\
\hline
\end{tabular}

\section{Analysis of peptide 2 epitope conservation and HLA distribution}

We used the peptide 2 sequence, YYVGYLQPRTFLLKY (amino acid 264-278), to compare with current posted SARS-CoV-2 variants including variant-of-interest (VOI) and variant-of-concern (VOC) published by WHO and observed that this sequence is highly conserved (Figure 4A), and located at the end of the NTD of Spike protein and upstream of the RBD (Figure 4B). The highly conserved epitopic sequence provides a useful tool for evaluating the CD8+ T cell-mediated responses to vaccination in animals and humans.

Since MHC-I-biased expression patterns in different populations globally are diversified and variable, the peptide 2 sequence that can be recognized by one population may not be recognized by others. To investigate if peptide 2 sequence could be recognized by most populations worldwide, we performed an HLA allele analysis for different regions to assess binding to one or more of the 27 prevalent $\mathrm{MHC}-\mathrm{I}$ molecules, including HLA-A (01:01, 02:01, 02:03, 02:06, 03:01, 11:01, 23:01, 24:02, 26:01, 30:01, 30:02, 31:01, 32:01, 33:01, 68:01, 68:02), and HLA-B (07:02, 08:01, 15:01, 35:01, 40:01, 44:02, 44:03, 51:01, 53:01, 57:01, 58:01), as shown in Figure 4C \& Table 4. The frequency by HLAs was calculated by the online analysis tool at http://www.allelefrequencies.net/. We also evaluated the MHC-I binding ability, immunogenicity, and TAP potential of peptide 2 on different HLA alleles by IEDB (Figure 4D \& Table 5). The results indicated that peptide 2 could be recognizable by the HLA-A*02:01 allele (most in Europe and America), HLA-B*08:01 allele (in Europe and Australia), HLA-A*23:01 allele (in North Africa and Sub-Saharan Africa), HLA-A*02:03 allele (in Southeast Asia), HLA-A*24:02 allele (in Oceania), HLA-A*02:06 allele (in North America, North-East Asia, and Oceania), HLA-A*33:01 allele (in China and Pakistan), HLA-B*35:01 allele (in Oceania), and HLA-A*03:01 allele (in Europe). These findings suggest that peptide 2 could be well recognized by the most frequent HLA alleles of the worldwide population and can therefore be considered to be promiscuous. 
Table 4

Geographic Distribution of HLA allele

\begin{tabular}{|c|c|c|c|c|}
\hline Continent & Allele & Frequency & Allele & Frequency \\
\hline \multirow[t]{3}{*}{ Australia } & $H L A-A * 24: 02$ & 0.2 & HLA-B*07:02 & 0.08 \\
\hline & HLA-A*02:01 & 0.11 & $H L A-B * 40: 01$ & 0.07 \\
\hline & HLA-A*11:01 & 0.08 & & \\
\hline \multirow[t]{4}{*}{ Europe } & $\mathrm{HLA}-\mathrm{A}^{\star 02: 01}$ & 0.26 & HLA-B*07:02 & 0.08 \\
\hline & HLA-A*01:01 & 0.12 & HLA-B*08:01 & 0.07 \\
\hline & HLA-A*03:01 & 0.12 & $H L A-B * 51: 01$ & 0.07 \\
\hline & $H L A-A * 24: 02$ & 0.1 & & \\
\hline \multirow[t]{3}{*}{ North Africa } & $\mathrm{HLA}-\mathrm{A} * 02: 01$ & 0.12 & HLA-B*51:01 & 0.07 \\
\hline & & & $H L A-B * 08: 01$ & 0.05 \\
\hline & & & HLA-B*35:01 & 0.05 \\
\hline \multirow[t]{6}{*}{ North America } & $\mathrm{HLA}-\mathrm{A} * 02: 01$ & 0.2 & HLA-B*35:01 & 0.08 \\
\hline & $H L A-A * 24: 02$ & 0.12 & $H L A-B * 07: 02$ & 0.07 \\
\hline & & & HLA-B*08:01 & 0.05 \\
\hline & & & HLA-B*15:01 & 0.05 \\
\hline & & & $H L A-B * 44: 03$ & 0.05 \\
\hline & & & HLA-B*51:01 & 0.05 \\
\hline \multirow[t]{5}{*}{ North-East Asia } & $H L A-A * 24: 02$ & 0.22 & HLA-B*51:01 & 0.08 \\
\hline & $\mathrm{HLA}-\mathrm{A} * 02: 01$ & 0.14 & HLA-B*35:01 & 0.07 \\
\hline & & & HLA-B*15:01 & 0.07 \\
\hline & & & HLA-B*44:03 & 0.06 \\
\hline & & & HLA-B*07:02 & 0.05 \\
\hline \multirow[t]{2}{*}{ Oceania } & $H L A-A * 24: 02$ & 0.3 & HLA-B*35:01 & 0.15 \\
\hline & HLA-A*11:01 & 0.15 & & \\
\hline \multirow[t]{2}{*}{ South and Central America } & $\mathrm{HLA}-\mathrm{A}^{\star} 02: 01$ & 0.2 & $H L A-B * 40: 01$ & 0.25 \\
\hline & $H L A-A * 24: 02$ & 0.14 & & \\
\hline South Asia & HLA-A*11:01 & 0.13 & & \\
\hline \multicolumn{5}{|l|}{ Notes } \\
\hline $\begin{array}{l}\text { 1. Frequency means the prop } \\
\text { the alleles for which frequen }\end{array}$ & $\begin{array}{l}\text { f HLA allele pr } \\
\text { igher than } 0.0\end{array}$ & $\begin{array}{l}\text { in the survey } \\
\text { he continent. }\end{array}$ & pulation. This $\mathrm{t}$ & only shows \\
\hline
\end{tabular}




\begin{tabular}{|lllll|}
\hline Continent & Allele & Frequency & Allele & Frequency \\
\hline & HLA-A*01:01 & 0.1 & & \\
\hline HLA-A*24:02 & 0.1 & & \\
\hline South-East Asia & HLA-A*11:01 & 0.2 & HLA-B*58:01 & 0.06 \\
\hline HLA-A*24:02 & 0.15 & HLA-B*07:02 & 0.06 \\
\hline Sub-Saharan Africa & HLA-A*23:01 & 0.11 & HLA-B*08:01 & 0.05 \\
\hline HLA-A*02:01 & 0.1 & & \\
\hline Western Asia & HLA-A*02:01 & 0.15 & \\
\hline & HLA-A*01:01 & 0.1 & \\
\hline Notes & & & \\
\hline $\begin{array}{l}\text { 1. Frequency means the proportion of HLA allele present in the survey population. This table only shows } \\
\text { the alleles for which frequency was higher than 0.05 in the continent. }\end{array}$ \\
\hline
\end{tabular}


Table 5

Human MHC-I epitope analysis for peptide 2

\begin{tabular}{|c|c|c|c|c|c|c|c|c|}
\hline Allele & $\begin{array}{l}\text { Peptide } \\
\text { number }\end{array}$ & $\begin{array}{l}\text { MHC-I } \\
\text { binding }\end{array}$ & Immunogenicity & $\begin{array}{l}\text { Proteasome } \\
\text { Score }\end{array}$ & $\begin{array}{l}\text { TAP } \\
\text { Score }\end{array}$ & $\begin{array}{l}\text { MHC } \\
\text { Score }\end{array}$ & $\begin{array}{l}\text { Processing } \\
\text { Score }\end{array}$ & $\begin{array}{l}\text { TAP } \\
\text { Total } \\
\text { Score }\end{array}$ \\
\hline $\begin{array}{l}\text { HLA- } \\
A^{*} 02: 01\end{array}$ & 2 & 0.02 & 0.18048 & 1.39 & 0.39 & -0.66 & 1.78 & 1.12 \\
\hline $\begin{array}{l}\text { HLA- } \\
B^{*} 08: 01\end{array}$ & 2 & 0.02 & 0.14268 & 1.39 & 0.39 & -1.31 & 1.78 & 0.47 \\
\hline $\begin{array}{l}\text { HLA- } \\
A^{*} 23: 01\end{array}$ & 2 & 0.03 & 0.19092 & 1.36 & 1.13 & -1.38 & 2.5 & 1.12 \\
\hline $\begin{array}{l}\text { HLA- } \\
A^{*} 02: 03\end{array}$ & 2 & 0.03 & 0.18064 & 1.39 & 0.39 & -0.91 & 1.78 & 0.87 \\
\hline $\begin{array}{l}\text { HLA- } \\
A^{*} 24: 02\end{array}$ & 2 & 0.04 & 0.19092 & 1.36 & 1.13 & -1.67 & 2.5 & 0.83 \\
\hline $\begin{array}{l}\text { HLA- } \\
A^{*} 02: 06\end{array}$ & 2 & 0.04 & 0.18064 & 1.39 & 0.39 & -0.96 & 1.78 & 0.82 \\
\hline $\begin{array}{l}\text { HLA- } \\
A^{*} 33: 01\end{array}$ & 2 & 0.09 & 0.18048 & 0.76 & 0.68 & -1.13 & 1.43 & 0.3 \\
\hline $\begin{array}{l}\text { HLA- } \\
B^{*} 35: 01\end{array}$ & 2 & 0.1 & 0.18064 & 1.41 & 1.19 & -2.35 & 2.6 & 0.25 \\
\hline $\begin{array}{l}\text { HLA- } \\
A^{*} 03: 01\end{array}$ & 2 & 0.12 & 0.18064 & 0.89 & 0.18 & -1.35 & 1.06 & -0.29 \\
\hline 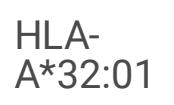 & 2 & 0.21 & 0.18064 & 1.39 & 0.39 & -2.21 & 1.78 & -0.43 \\
\hline $\begin{array}{l}\text { HLA- } \\
B^{\star} 53: 01\end{array}$ & 2 & 0.21 & 0.18064 & 1.41 & 1.19 & -3.4 & 2.6 & -0.8 \\
\hline $\begin{array}{l}\text { HLA- } \\
A^{*} 01: 01\end{array}$ & 2 & 0.23 & 0.18424 & 1.41 & 1.24 & -2.91 & 2.65 & -0.26 \\
\hline $\begin{array}{l}\text { HLA- } \\
B^{\star} 15: 01\end{array}$ & 2 & 0.29 & 0.18064 & 1.41 & 1.28 & -1.79 & 2.69 & 0.89 \\
\hline $\begin{array}{l}\text { HLA- } \\
A^{*} 30: 02\end{array}$ & 2 & 0.35 & 0.19092 & 1.41 & 1.28 & -2.29 & 2.69 & 0.4 \\
\hline $\begin{array}{l}\text { HLA- } \\
A^{\star 31: 01}\end{array}$ & 2 & 0.45 & 0.18064 & 0.76 & 0.68 & -1.9 & 1.43 & -0.47 \\
\hline
\end{tabular}

\section{Notes}

4. MHC-I binding score was between 0 and 2. $<0.5$ strong binder, 0.5-2 weak binder, $>2$ non-binder.

5. The high Immunogenicity score means the degree of the peptide conformity to sequence preference was good.

6. The higher the TAP total score, the higher the likelihood that the peptide will be presented after being swallowed by DCs. 


\begin{tabular}{|c|c|c|c|c|c|c|c|c|}
\hline Allele & $\begin{array}{l}\text { Peptide } \\
\text { number }\end{array}$ & $\begin{array}{l}\text { MHC-I } \\
\text { binding }\end{array}$ & Immunogenicity & $\begin{array}{l}\text { Proteasome } \\
\text { Score }\end{array}$ & $\begin{array}{l}\text { TAP } \\
\text { Score }\end{array}$ & $\begin{array}{l}\text { MHC } \\
\text { Score }\end{array}$ & $\begin{array}{l}\text { Processing } \\
\text { Score }\end{array}$ & $\begin{array}{l}\text { TAP } \\
\text { Total } \\
\text { Score }\end{array}$ \\
\hline $\begin{array}{l}\text { HLA- } \\
A^{\star} 26: 01\end{array}$ & 2 & 0.52 & 0.18048 & 1.41 & 1.28 & -4.14 & 2.69 & -1.45 \\
\hline $\begin{array}{l}\text { HLA- } \\
A^{\star} 11: 01\end{array}$ & 2 & 0.53 & 0.18064 & 0.89 & 0.18 & -1.63 & 1.06 & -0.57 \\
\hline $\begin{array}{l}\text { HLA- } \\
B * 58: 01\end{array}$ & 2 & 0.55 & 0.18064 & 1.36 & 1.06 & -3.33 & 2.42 & -0.9 \\
\hline $\begin{array}{l}\text { HLA- } \\
B^{*} 57: 01\end{array}$ & 2 & 0.56 & 0.18064 & 1.36 & 1.07 & -3.39 & 2.43 & -0.95 \\
\hline $\begin{array}{l}\text { HLA- } \\
B^{*} 51: 01\end{array}$ & 2 & 0.65 & 0.18064 & 1.41 & 1.28 & -4.36 & 2.69 & -1.67 \\
\hline $\begin{array}{l}\text { HLA- } \\
B^{\star} 07: 02\end{array}$ & 2 & 0.72 & 0.18064 & 1.41 & 1.19 & -3.75 & 2.6 & -1.15 \\
\hline $\begin{array}{l}\text { HLA- } \\
A^{*} 30: 01\end{array}$ & 2 & 0.73 & 0.18424 & 1.41 & 1.28 & -3.73 & 2.69 & -1.05 \\
\hline $\begin{array}{l}\text { HLA- } \\
A^{\star} 68: 02\end{array}$ & 2 & 1.4 & 0.18064 & 1.39 & 0.39 & -3.11 & 1.78 & -1.33 \\
\hline $\begin{array}{l}\text { HLA- } \\
B^{*} 44: 03\end{array}$ & 2 & 1.6 & 0.18424 & 1.41 & 1.28 & -4.01 & 2.69 & -1.33 \\
\hline $\begin{array}{l}\text { HLA- } \\
B^{*} 44: 02\end{array}$ & 2 & 1.9 & 0.18424 & 1.41 & 1.28 & -4.16 & 2.69 & -1.47 \\
\hline $\begin{array}{l}\text { HLA- } \\
A^{*} 68: 01\end{array}$ & 2 & 2.4 & 0.18064 & 0.76 & 0.68 & -2.33 & 1.43 & -0.9 \\
\hline $\begin{array}{l}\text { HLA- } \\
B^{\star} 40: 01\end{array}$ & 2 & 3.1 & 0.18048 & 1.41 & 1.28 & -4.44 & 2.69 & -1.75 \\
\hline \multicolumn{9}{|l|}{ Notes } \\
\hline \multicolumn{9}{|c|}{ 4. MHC-I binding score was between 0 and 2. $<0.5$ strong binder, $0.5-2$ weak binder, $>2$ non-binder. } \\
\hline \multicolumn{9}{|c|}{$\begin{array}{l}\text { 5. The high Immunogenicity score means the degree of the peptide conformity to sequence preference was } \\
\text { good. }\end{array}$} \\
\hline \multicolumn{9}{|c|}{$\begin{array}{l}\text { 6. The higher the TAP total score, the higher the likelihood that the peptide will be presented after being } \\
\text { swallowed by DCs. }\end{array}$} \\
\hline
\end{tabular}

\section{Discussion}

In this study, we have defined and characterized a potential CTL epitope conserved and established a BALB/C mice model to evaluate CTL responses to the spike protein of SARS-CoV-2. Furthermore, we found the peptide 2 may be well recognized by HLA alleles in most populations worldwide. 
In recent studies, CD8+ T cell immunity was found to make major contributions to the protective efficacy of SARS-CoV-2 vaccines ${ }^{15-17}$. Additionally, lymphopenia was more accentuated in symptomatic COVID-19 patients with pneumonia than in those without pneumonia, consistent with $T$ cell immunity playing a protective role in pre-existing immunity against SARS-CoV-2 ${ }^{17-19}$. However, the role of T cell immunity in the pathology of COVID-19 has not been clarified ${ }^{20}$ and awaits further definition of $T$ cell epitopes and their functions. Engineered improvements in the peptide epitopes recognized by CTL have been an essential feature of the advancements made in evaluating the cellular immunity induced by vaccines. Our work has provided a tool to monitor virus-specific CD8+ T cells and assess the contribution of CTLs to the control and the elimination of the virus.

The SARS-CoV-2 virus was found to mutate rapidly, the development of vaccines that could protect people from different variants was seen to be urgent. The neutralizing antibodies induced by vaccines were found to have variable efficacies against the different SARS-CoV-2 variants and efficacies declined over time, whereas the protection represented by $\mathrm{CD}^{+} \mathrm{T}$ cell immunity remained unchanged ${ }^{15}$. We showed here that one particular peptide from the spike protein, peptide 2 is highly conserved among variants and could be well presented by MHC-1 of all of the HLA alleles that are most frequent worldwide. Thus, the conserved peptide 2 was found suitable for developing peptide vaccines to induce cellular immunity against different variants of SARS-CoV-2, including variant-of-interest (VOI) and variant-of-concern (VOC). A recent study confirmed that peptide 2 probably has a strong cell-mediated immunological function in man; a 9-mer (YLQPRTFLL) peptide that was overlapped by peptide 2 was able to induce a high level of IFN-y expression from PBMCs of patients who had recovered from COVID-19 and carried the HLA-A*02:01 allele ${ }^{21}$.

In conclusion, our study utilized web-based tools to predict human MHC-I epitopes although peptide 2 (YYVGYLQPRTFLLKY) did not give the strongest total TAP score in the prediction, the simulations indicated particularly robust antigen-specific IFN- $y$-expressing CD8+ T responses overall compared to the other predicted epitope sequences. This epitope sequence is highly conservative among currently known SARS-CoV-2 variants and recognizable by most world populations. This critical MHC-I epitope sequence is located at the end of NTD of the spike protein; it can be used to assess CMI induced by a COVID-19 vaccination; it may be strategically incorporated into vaccine designs to enhance the prospect of viral elimination by vaccination.

\section{Materials And Methods}

\section{Mice}

Female BALB/c mice (6-8 weeks of age) were purchased from Beijing Vital Laboratory Animal Technology Co., Ltd. (Beijing, China) and Shanghai Jiesjie Laboratory Animal Co., Ltd. (Shanghai, China), and were kept in SPF conditions. All animal experiments were approved by the Experimental Animals Committee of SHMC, and all methods were carried out in accordance with relevant guidelines and regulations. This study was carried out in compliance with the ARRIVE guidelines. All mice was sacrificed after experiment under euthanasia with Isoflurane overdose.

\section{Peptide pool derived from SARS-CoV-2 Spike protein}


The spike receptor-binding domain (RBD) peptide pool (SARS-CoV-2 spike protein 258-518aa) published previously ${ }^{7}$ was used for the study (Table 1 ).

\section{Immunization}

The mice were injected twice, with a two-week interval, via the intramuscular route (i.m.) with $25 \mu \mathrm{gg}$ p X9501 expressing a synthetic, optimized sequence of the SARS-CoV-2 full-length spike glycoprotein ${ }^{7}$ and then electroporation was applied with the Cellectro2000 device. Serum samples and spleens were collected 14 days after the second immunization.

\section{Cytotoxic lymphocyte (CTL) killing ability}

A single-cell suspension of splenocytes from naïve syngeneic mice was diluted to $1.5^{\star} 10^{8} / \mathrm{ml}$ in RPMI1640 containing $10 \% \mathrm{FBS}$ and $2 \%$ penicillin and streptomycin and pulsed at $37^{\circ} \mathrm{C}$ with or without $5 \mathrm{ug} / \mathrm{ml}$ peptides as described previously ${ }^{22}$. After 4 h, eflour450 (eBioscience, 65-0842-85) at $5 \mathrm{mM}$ (high concentration) was used to label peptide-pulsed cells at room temperature in the dark. The non-peptide-pulsed cells were labeled with a low concentration of eflour450 at $0.5 \mathrm{mM}$. After being rinsed three times with PBS, $4^{\star} 10^{6}$ labeled and peptide-pulsed cells and an equal number of labeled non-peptide-pulsed cells were adoptively transferred by tail vein injections into mice that had previously been immunized. Six hours later, the percentage of labeled cells in spleens was detected with LSRFortessa flow cytometry (BD) and analyzed by FlowJo (TreeStar). The following formula calculated the specific cell lysis: Specific cell lysis ability $=$ (1-(percentage of cells incubated with peptide/percentage of cells incubated without peptide)) *100\%.

\section{IFN-ץ ELIspot}

Spleens were collected from mice individually into RPMI1640 media supplemented with 10\% FBS (Gibco) and penicillin/streptomycin and processed into single-cell suspensions. ELIspot assays were performed using Mouse IFN-y ELIspot plates (Dakewei Biotech Co., Ltd, 2210006). The ELIspot plates were repeat washed 5 times at RT with $100 \mu \mathrm{L}$ of PBS per well and incubated with $200 \mu \mathrm{L}$ of RPMI1640 10\% FBS (R10) for 10 min before cell plating. Two hundred fifty thousand mouse splenocytes, CD4+, or CD8+ T cells were plated into each well and stimulated for $16 \mathrm{~h}$ with 15-mer peptides from the SARS CoV-2 Spike peptide pools that overlapped by nine amino acids as previously described ${ }^{7}$. Each peptide was present at a final concentration of $1 \mu \mathrm{g}$ in $100 \mu \mathrm{l}$ R10 per well. The spots were developed based on the manufacturer's instructions. R10 and cell stimulation cocktails (Invitrogen) were used for negative and positive controls, respectively. Spots were scanned and quantified by AID ELIspot READER (AID, Germany). Spot-forming units (SFU) per million cells were calculated after subtracting the negative control wells.

\section{Statistical Analysis}

The statistical analysis methods and sample sizes (n) are specified in the results section or figure legends for all quantitative data. All values are reported as means \pm sem with the indicated sample size. No samples are excluded from the analysis. All relevant statistical tests are two-sided. P values less than 0.05 were considered statistically significant. All animal studies were performed with randomized animal selection. Statistics were performed using GraphPad Prism 7 software. In all data, ${ }^{*} p<0.05,{ }^{\star *} p<0.01$, ${ }^{\star *} p<0.001$, and ${ }^{* \star * *} p<0.0001$. 


\section{Declarations}

\section{ACKNOWLEDGMENT}

This work was supported by the Chinese National Natural Science Foundation (81991492 and 82041039) and National Key R\&D Program of China (2018YFC0840402) to B.Wang.

\section{COMPETING INTERESTS}

Authors declare that they have no competing interests.

\section{AUTHOR CONTRIBUTIONS}

BW and SJ conceived, designed the study and drafted manuscript. BW supervised the study. SJ, SW, XG, JH, $Y D$ and ZZ performed the experiments. SJ, YH, GZ and AC analyzed the data. All authors reviewed the manuscript.

\section{References}

1. Li, Q. et al., Early Transmission Dynamics in Wuhan, China, of Novel Coronavirus-Infected Pneumonia. The New England journal of medicine 3821199 (2020).

2. Pal, M., Berhanu, G., Desalegn, C. \& Kandi, V., Severe Acute Respiratory Syndrome Coronavirus-2 (SARSCoV-2): An Update. Cureus 12 e7423 (2020).

3. Sakamoto, A. et al., ACE2 (Angiotensin-Converting Enzyme 2) and TMPRSS2 (Transmembrane Serine Protease 2) Expression and Localization of SARS-CoV-2 Infection in the Human Heart. Arteriosclerosis, Thrombosis, and Vascular Biology (2020).

4. Huang, W. C. et al., SARS-CoV-2 RBD Neutralizing Antibody Induction is Enhanced by Particulate Vaccination. ADV MATER 322005637 (2020).

5. Kreye, J. et al., A SARS-CoV-2 neutralizing antibody protects from lung pathology in a COVID-19 hamster model. bioRxiv (2020).

6. Wu, S. et al., A single dose of an adenovirus-vectored vaccine provides protection against SARS-CoV-2 challenge. NAT COMMUN 11 (2020).

7. Smith, T. et al., Immunogenicity of a DNA vaccine candidate for COVID-19. NAT COMMUN 112601 (2020).

8. Lu, J. et al., A COVID-19 mRNA vaccine encoding SARS-CoV-2 virus-like particles induces a strong antivirallike immune response in mice. CELL RES 30936 (2020).

9. Muraoka, D. et al., Identification of a dominant CD8(+) CTL epitope in the SARS-associated coronavirus 2 spike protein. VACCINE 387697 (2020).

10. Reynisson, B., Alvarez, B., Paul, S., Peters, B. \& Nielsen, M., NetMHCpan-4.1 and NetMHCllpan-4.0: improved predictions of $\mathrm{MHC}$ antigen presentation by concurrent motif deconvolution and integration of MS MHC eluted ligand data. NUCLEIC ACIDS RES 48 W449 (2020).

11. Balendiran, G. K. et al., The three-dimensional structure of an H-2Ld-peptide complex explains the unique interaction of Ld with beta-2 microglobulin and peptide. Proc Natl Acad Sci U S A 946880 (1997). 
12. Speir, J. A. et al., Structural basis of 2C TCR allorecognition of H-2Ld peptide complexes. Immunity (Cambridge, Mass.) 8553 (1998).

13. Suri, A., Walters, J. J., Levisetti, M. G., Gross, M. L. \& Unanue, E. R., Identification of naturally processed peptides bound to the class I MHC molecule H-2Kd of normal and TAP-deficient cells. EUR J IMMUNOL 36 544 (2006).

14. CORR, M., BOYD, L. F., PADLAN, E. A. \& MARGULIES, D. H., H-2Dd exploits a four residue peptide binding motif. The Journal of experimental medicine 1781877 (1993).

15. Alter, G. et al., Immunogenicity of Ad26.COV2.S vaccine against SARS-CoV-2 variants in humans. Nature (London) (2021).

16. DiPiazza, A. T., Graham, B. S. \& Ruckwardt, T. J., T cell immunity to SARS-CoV-2 following natural infection and vaccination. Biochem Biophys Res Commun 538211 (2021).

17. Zhang, G. et al., Analysis of clinical characteristics and laboratory findings of 95 cases of 2019 novel coronavirus pneumonia in Wuhan, China: a retrospective analysis. RESP RES 2174 (2020).

18. Bonifacius, A. et al., COVID-19 immune signatures reveal stable antiviral T cell function despite declining humoral responses. IMMUNITY 54340 (2021).

19. Wang, F. et al., Characteristics of Peripheral Lymphocyte Subset Alteration in COVID-19 Pneumonia. The Journal of infectious diseases 2211762 (2020).

20. Muraoka, D. et al., Identification of a dominant CD8(+) CTL epitope in the SARS-associated coronavirus 2 spike protein. VACCINE 387697 (2020).

21. Agerer, B. et al., SARS-CoV-2 mutations in MHC---restricted epitopes evade CD8+ T cell responses. Science Immunology 6 g6461 (2021).

22. Clemente, T., Dominguez, M. R., Vieira, N. J., Rodrigues, M. M. \& Amarante-Mendes, G. P., In vivo assessment of specific cytotoxic T lymphocyte killing. METHODS 61105 (2013).

\section{Figures}




\section{Figure 1}

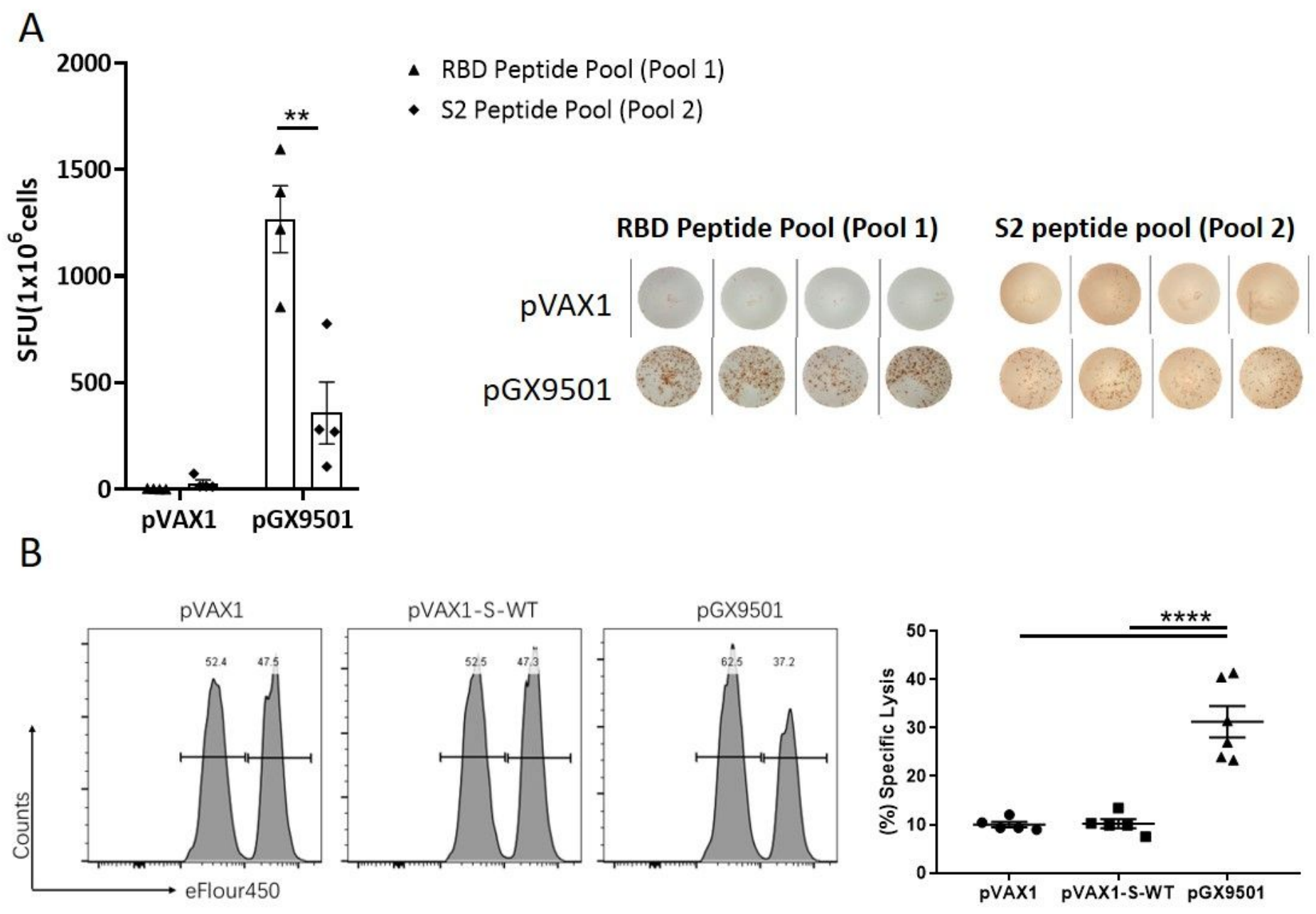

Figure 1

Peptide pool 1 Induced strong T cell responses in BALB/c mice post-administration of pGX9501 Balb/c mice (n

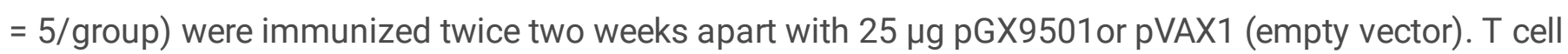
responses were analyzed on day 14 after the second injection. (A) Splenocytes were harvested and $T$ cell responses were measured by IFN- $\gamma$ ELIspot after stimulation for $20 \mathrm{~h}$ with overlapping peptide pools 1 or 2. (B) Antigen-specific cytotoxic lymphocyte (CTL) killing activity was evaluated by an in vivo CTL assay. Target cells at $4 * 106 / \mathrm{ml}$ from naïve mice were peptide-pulsed with pool 1 then labeled with a high concentration of eFlour450 in vitro Control cells were non-peptide-pulsed cells and labeled with a low concentration of eFluor450.The cells were mixed and transferred i.v. into immunized mice. After $5 \mathrm{~h}$, splenocytes were harvested and the intensity of eFlour450 peptide labeled target cells was compared with the non-peptide-labeled negative control cells by flow cytometry. 


\section{Figure 2}

A
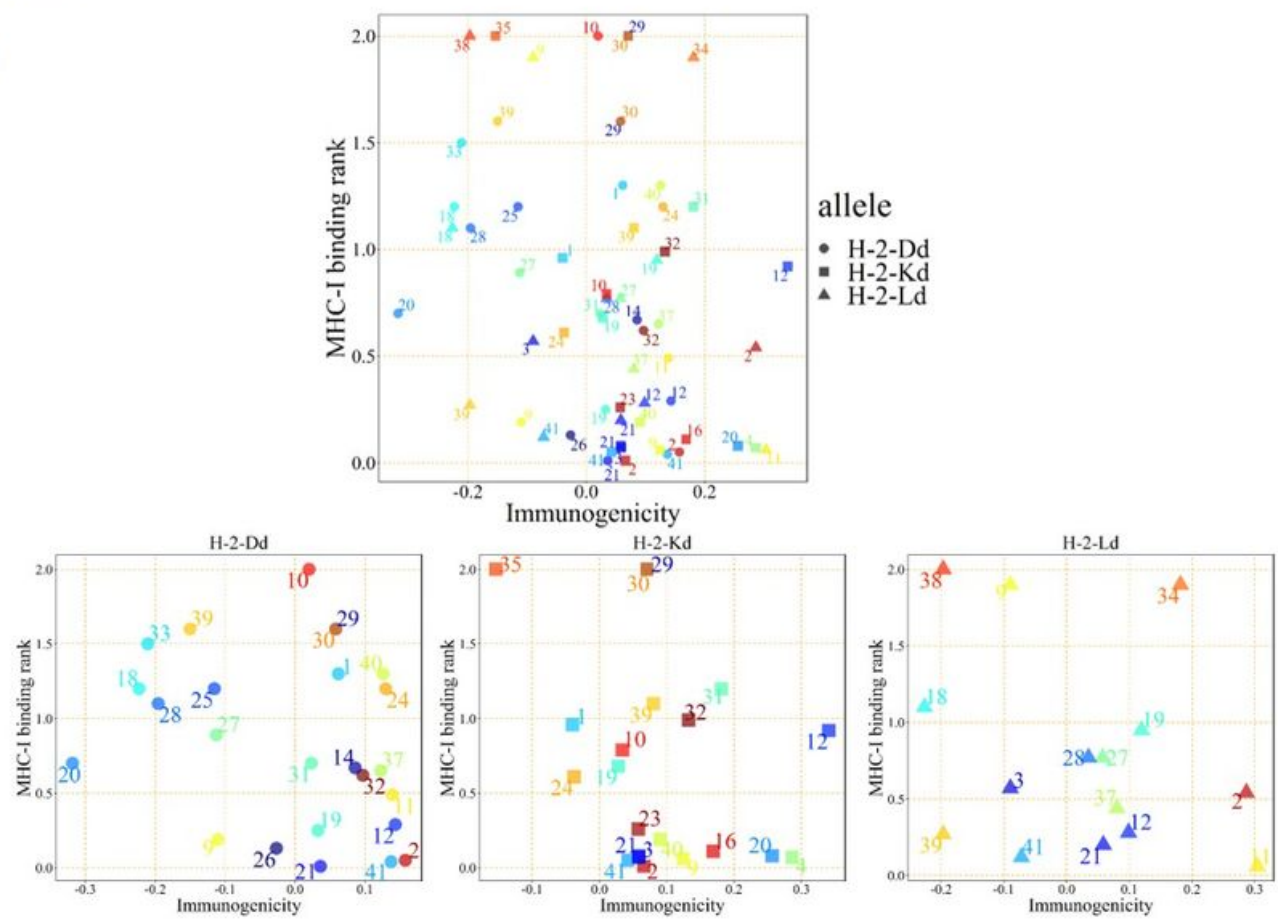

B
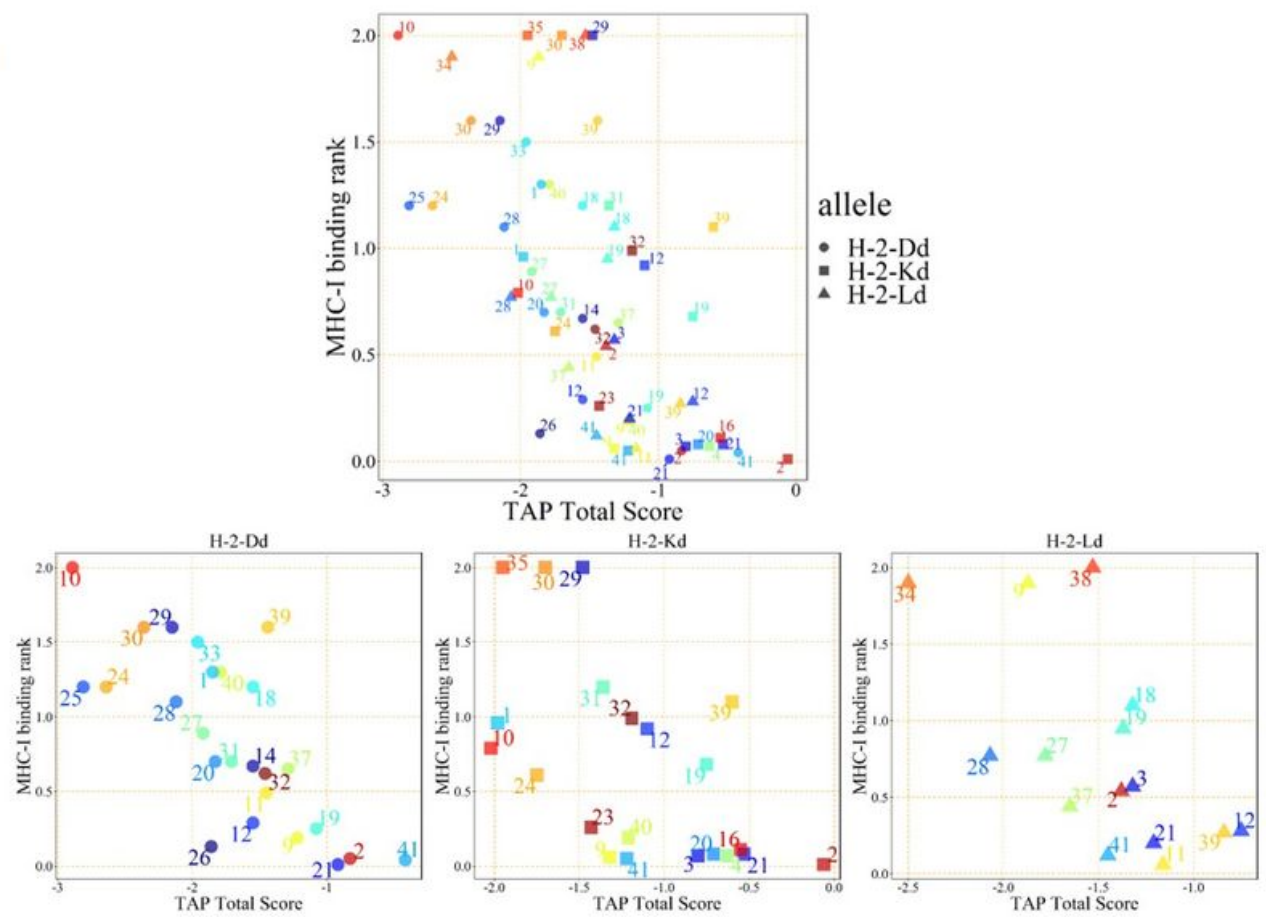

Figure 2

IEDB prediction scores of peptides in pool 1 CTL epitope peptides were screened by integrating MHC-I binding prediction, MHC-I immunogenicity (A), and MHC-NP (B) prediction from three $\mathrm{H}-2 \mathrm{~d} \mathrm{MHC}-\mathrm{I}$ alleles. 
Figure 3
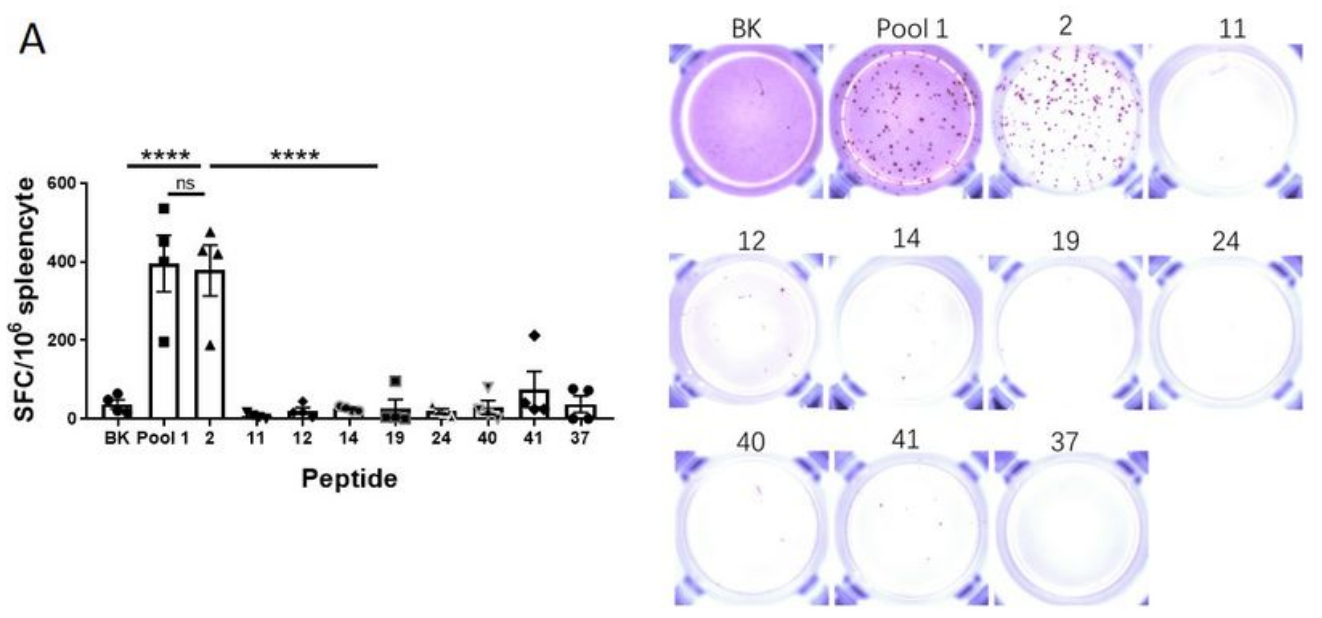

B
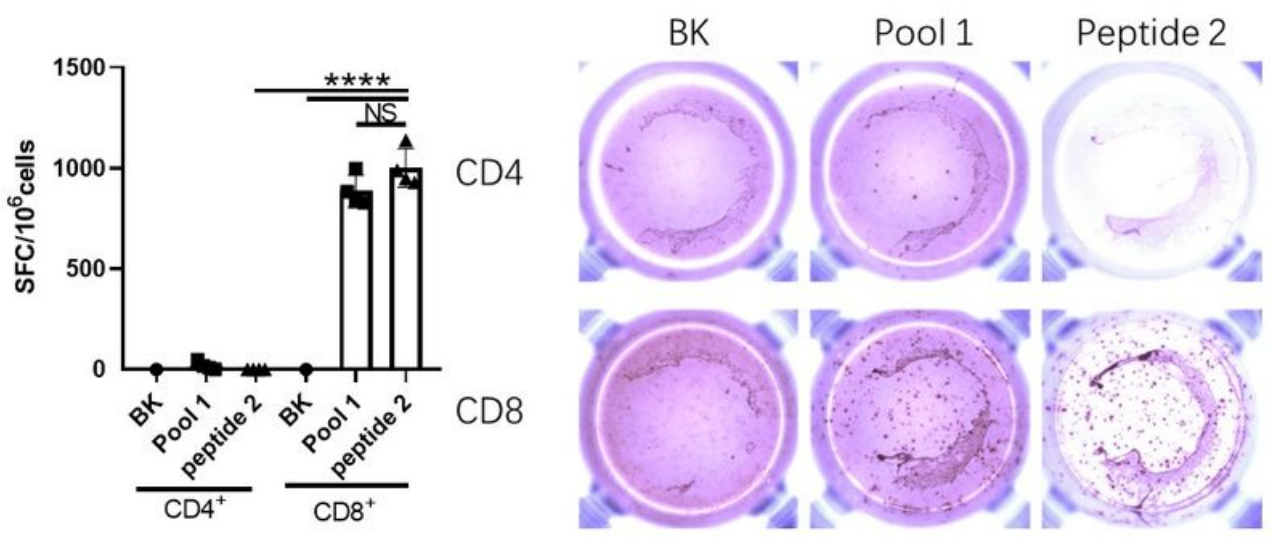

C
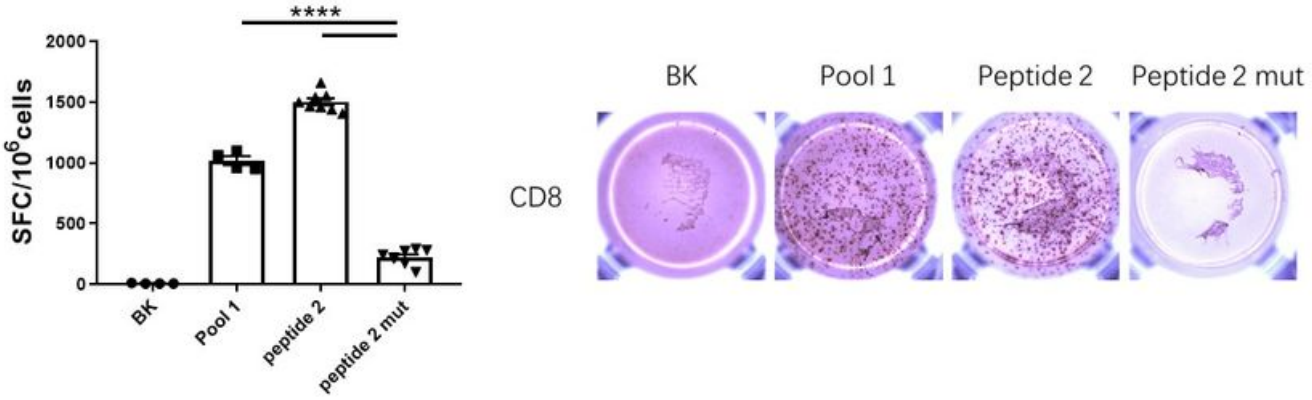

Figure 3

Peptide 2 is identified as the CD8+ CTL epitope BALB/c mice were immunized with the pGX9501. Splenocytes were obtained and specific T-cell induction was analyzed with IFN-y ELIspot, using stimulation with the indicated peptides. (A) Splenocytes, (B) CD4+, and (C) CD8+ T cells. 


\section{Figure 4}

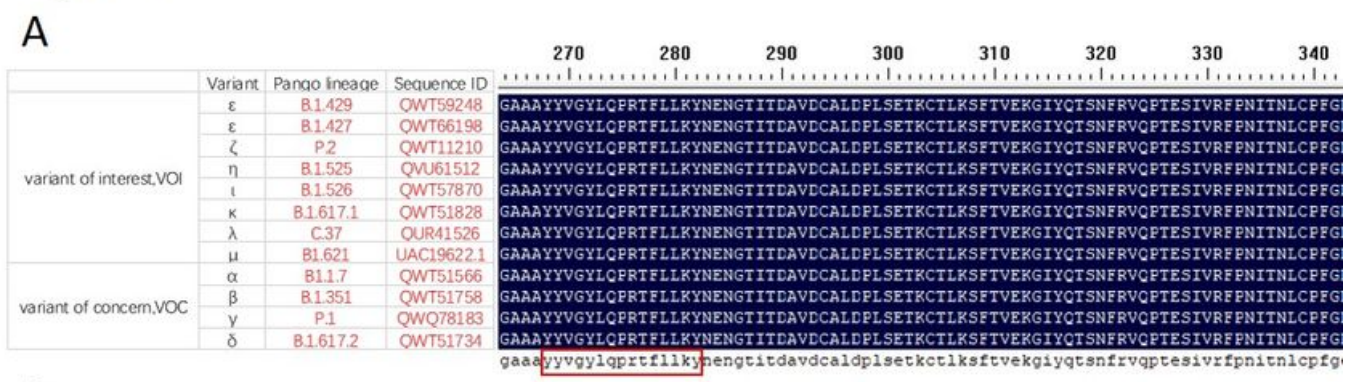

B

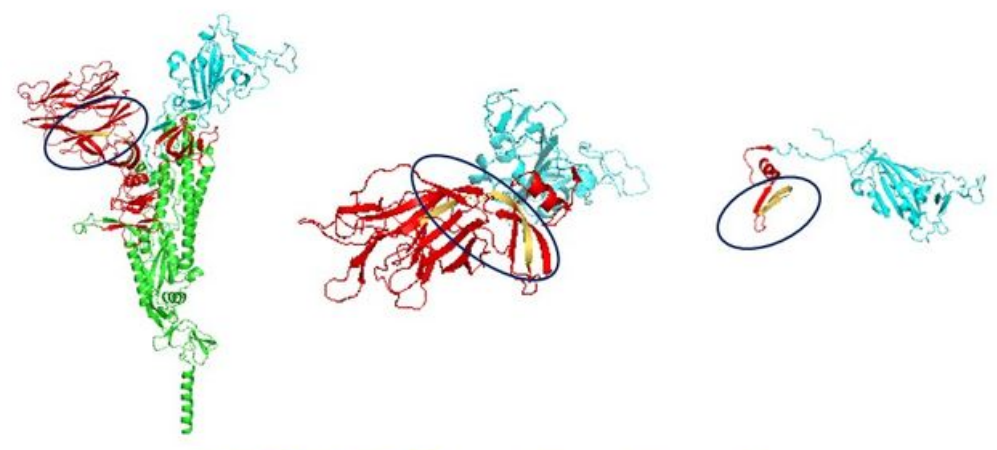

C

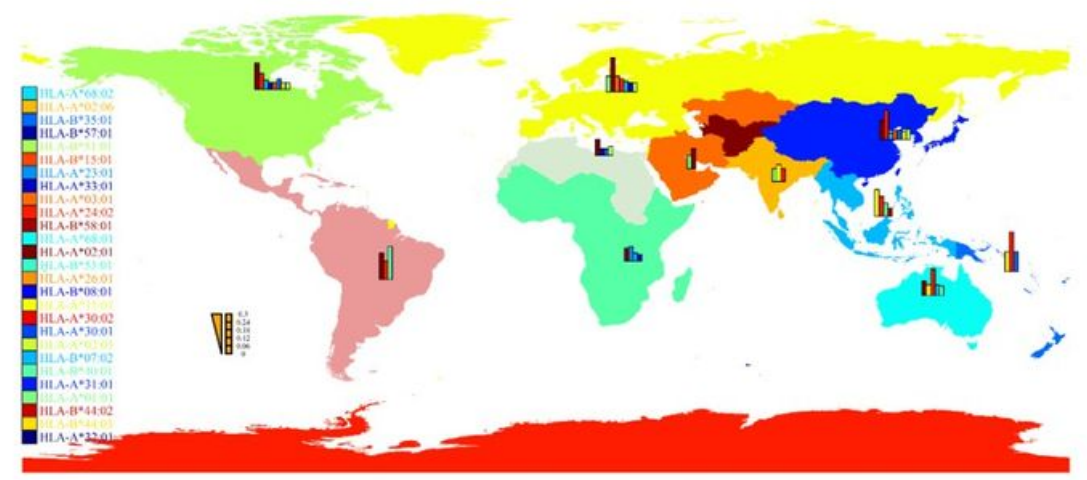

D
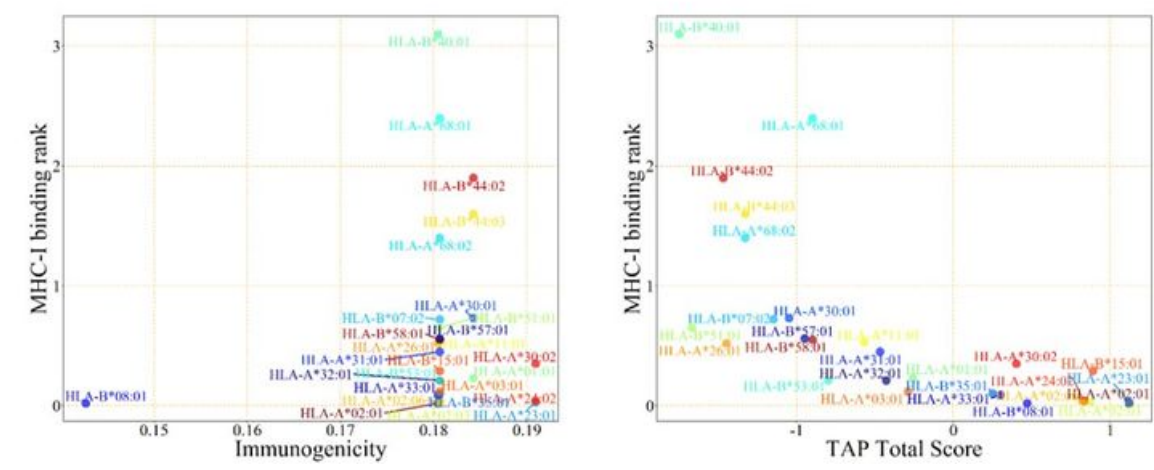

Figure 4

Conserved Sequence \& MHC-I HLA Analysis of peptide 2 (A) The sequence of peptide 2 was highly conserved in the 11 virus variants that have been identified as the variants of interest and the variants of concern, as published by WHO. (B) The position of the peptide in the stereoscopic structure of the spike protein. (C) The global distribution of HLA alleles. (D) Analysis of peptide 2 by integration of MHC-I binding prediction, MHC-I immunogenicity, and MHC-NP prediction from the HLA alleles.

\section{Supplementary Files}


This is a list of supplementary files associated with this preprint. Click to download.

- sFigure1.docx 